Cite this as: BMJ 2020;369:m2435 http://dx.doi.org/10.1136/bmj.m2435 Published: 18 June 2020

\section{Routine vaccination during covid-19 pandemic response}

An editorial error in this article by Sonia Saxena and colleagues (BMJ 2020;369:m2393; doi:) resulted in incorrect reference numbering in the text. In addition, Helen Bedford not Helen Skirrow is member of the health improvement committee of Royal College of Paediatrics and Child Health. These errors have been corrected in the online version. 